\title{
Stalagmite-inferred Holocene precipitation in northern Guizhou Province, China, and asynchronous termination of the Climatic Optimum in the Asian monsoon territory
}

\author{
JIANG XiuYang ${ }^{1 *}$, HE YaoQi ${ }^{2}$, SHEN ChuanChou ${ }^{3 *}$, KONG XingGong $^{4}$, LI ZhiZhong ${ }^{1}$ \& \\ CHANG YuWei ${ }^{3}$
}

\author{
${ }^{1}$ Key Laboratory of Humid Subtropical Eco-geographical Processes, Ministry of Education, College of Geography Science, Fujian Normal Uni- \\ versity, Fuzhou 350007, China; \\ ${ }^{2}$ College of Tourism and Air Service, Guizhou Minzu University, Guiyang 550025, China; \\ ${ }^{3}$ High-Precision Mass Spectrometry and Environment Change Laboratory (HISPEC), Department of Geosciences, Taiwan University, Taipei 106, \\ China; \\ ${ }^{4}$ College of Geography Science, Nanjing Normal University, Nanjing 210046, China
}

Received May 8, 2011; accepted September 8, 2011; published online November 19, 2011

\begin{abstract}
An absolute-dated, bi-decadal-resolution, stalagmite oxygen-isotopic time series from Shigao Cave reveals the evolution of summer monsoon precipitation over the past $9.9 \mathrm{ka}$ BP in northern Guizhou Province, Southwest China. The $\delta^{18} \mathrm{O}$-inferred climate conditions are divisible into three distinct stages: (1) a maximum humid era from 9.9-6.6 ka BP; (2) a gradual declining precipitation interval between 6.6-1.6 ka BP; and (3) a relatively low precipitation time window after 1.6 ka BP. Consistency of contemporaneous stalagmite Holocene $\delta^{18} \mathrm{O}$ records between Shigao and other caves in the Indian and East Asian monsoon realms support the effect of primary orbital solar forcings on monsoonal precipitation. However, statistical analysis shows a significant spatial asynchroneity of the Holocene Optimum termination in the Asian monsoon territory. The Holocene Optimum ended at 7.2-7.4 ka BP in Oman, located in the Indian monsoon region, and at 5.6-5.8 ka BP in Central China, in the East Asian monsoon zone. In Southwest China, the termination occurred between these periods, at 6.6-7.0 ka BP, and was influenced by both monsoon systems. We propose that this spatially asynchronous ending of Holocene Optimum in Asia may be attributed to sea surface temperature changes in the western tropical Pacific, which is a primary moisture source for the East Asian monsoon.
\end{abstract}

Holocene Climatic Optimum, Indian monsoon, East Asian monsoon, asynchroneity, Shigao Cave, stalagmite oxygen isotopes

Citation: Jiang X Y, He Y Q, Shen C C, et al. Stalagmite-inferred Holocene precipitation in northern Guizhou Province, China, and asynchronous termination of the Climatic Optimum in the Asian monsoon territory. Chin Sci Bull, 2012, 57: 795-801, doi: 10.1007/s11434-011-4848-6

Holocene climate has been essential to the development of modern Chinese civilization, affecting agriculture, economy, culture, prosperity and dynasty alternation. Recent studies have led to significant advances in understanding of Asian Monsoon (AM) dynamics during the Holocene [1-18]. However, the timing, duration and transition of the Holocene Optimum are still under debate. In 1992, Shi et al. [15] suggested that a so-called Holocene Megathermal Period

*Corresponding authors (email: strawjxy@msn.com; river@ntu.edu.tw) occurred in China at 8.5-3.0 ka BP. On the basis of multiproxy geological data from China, Shi et al. [15] discovered a wettest and warmest event, the Megathermal Maximum, which lasted from 7.2-6.0 ka BP. The proposed climatic evolution was supported by a study of monsoon/arid transition belt in North China, using sedimentary geochemistry recorded in Daihai Lake [16]. An et al. [1] reported asynchronous regional timings of this Holocene Optimum, at 9.0 $\mathrm{ka} \mathrm{BP}$ in north and northeast China, and as late as $3.0 \mathrm{ka} \mathrm{BP}$ in south and southeast China. However, a multi-proxy anal- 
ysis of high-resolution sequences of eutrophic peat/mud, sand dune, and loess/paleosol deposits showed that the Holocene Optimum occurred between 10.0-5.0 ka BP in both southern and northern China [17]. This information does not support the transgressive model described by An et al. [1]. High-resolution pollen records from Huguangyan Maar Lake have shown a different time window for the climatic optimum at 9.5-8.0 ka BP in southern China [18]. These conflicting reports could be caused by (1) uncertainties in chronology or sampling resolution and/or (2) different climate responses and feedback processes for different natural biogeochemical archives.

Stalagmites have advantages of absolute and high-precision chronology and abundant proxies, and have been used to decipher Holocene monsoon history [6-14]. Comparisons of Sanbao Cave records with regional speleothem records prompted Dong et al. [8] to suggest that the Holocene Optimum was at 9.5-6.5 ka BP in both Indian (IM) and East Asian monsoon (EAM) systems. However, stalagmite $\delta^{18} \mathrm{O}$ records from different latitudes have shown asynchronous onsets of declining Holocene summer monsoon precipitation trends over the entire East Asian region [9]. The dispute over a stalagmite-inferred Holocene Optimum is likely caused by a lack of reliable, objective statistical analysis on cave $\delta^{18} \mathrm{O}$ records.

Here, we present a high-resolution and ${ }^{230}$ Th-dated monsoon record generated with two Holocene stalagmites collected from Shigao Cave, northern Guizhou Province, Southwest China. We compared this record with other records from both IM and EAM systems by a well-developed time-series analysis method to clarify the temporal-spatial patterns of regional Holocene optima in the two monsoon territories. Based on these analyses, we propose possible forcings on these stalagmite-inferred climate sequences.

\section{Site description and methods}

\subsection{Regional settings}

Shigao Cave $\left(107^{\circ} 10^{\prime} \mathrm{E}, 28^{\circ} 11^{\prime} \mathrm{N}\right)$ is located in the Shuanghedong National Geological Park in Suiyang, about $80 \mathrm{~km}$ northeast of Zuiyi City, Guizhou Province, Southwest China (Figure 1). The regional climate experiences typical subtropical monsoon systems and is characterized by four distinct seasons. These include rainy in hot summer and drought in cold winter. The local temperature ranges from $1.6^{\circ} \mathrm{C}$ in winter and $22.5^{\circ} \mathrm{C}$ in summer and the annual mean (AD 1950-2000) temperature is $13.5^{\circ} \mathrm{C}$, recorded at the nearest meteorological station. Cave temperature is $13.0^{\circ} \mathrm{C}$. The mean annual precipitation is $1160-1350 \mathrm{~mm}$. The soil layer overlying the cave is mainly composed of yellow soil and calcareous soil. The well-developed vegetation mainly consists of subtropical broadleaf evergreen and deciduous mixed forests.

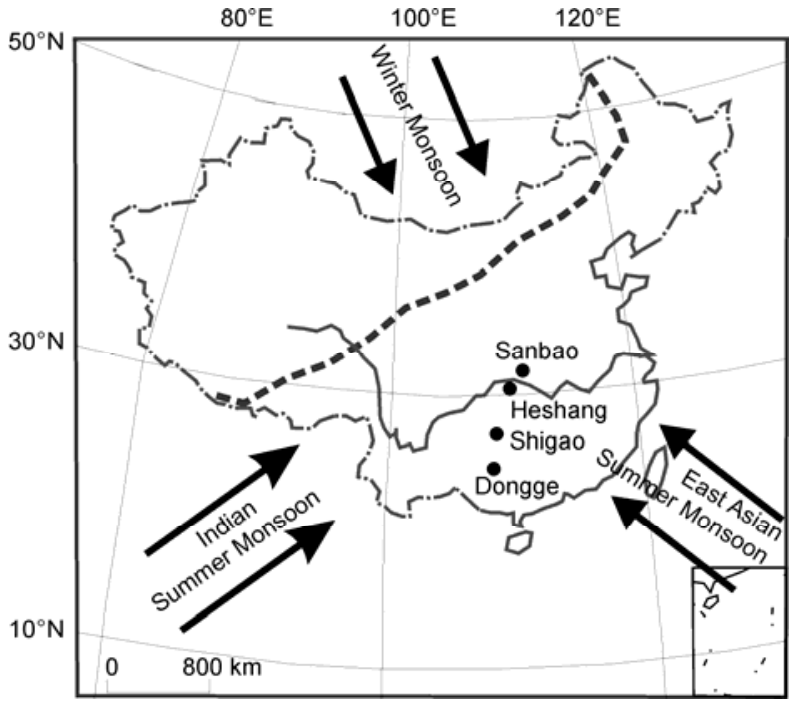

Figure 1 Map with Shigao $\left(107^{\circ} 10^{\prime} \mathrm{E}, 28^{\circ} 11^{\prime} \mathrm{N}\right)$, Dongge, Heshang, and Sanbao Caves and the modern monsoon systems in China. The dashed line represents the averaged modern summer Asian monsoon limit.

\subsection{Samples and methods}

Two calcite stalagmites, SG1 and SG 2, were collected in June 2010, approximately $400 \mathrm{~m}$ from the Shigao Cave entrance. Stalagmite SG1 was $273 \mathrm{~mm}$ in height and $10 \mathrm{~cm}$ in diameter, and SG2 was $205 \mathrm{~mm}$ in height and $8 \mathrm{~cm}$ in diameter. The two stalagmites were split in half using a diamond saw. The two stalagmites constitute pure calcite without any pores on the polished surface, and are composed of typical coalescent columnar-fabric crystals. An apparent unconformity was observable at a depth of 4-5 $\mathrm{mm}$ from the top of SG1. No visible hiatus was found for sample SG2. Twelve layers in total were drilled from stalagmites SG1 and SG2 for ${ }^{230} \mathrm{Th}$ dating on a Finnigan NEPTUNE Multi-collection inductively coupled plasma mass spectrometer (MC-ICP-MS) in the High-precision Mass Spectrometry and Environment Change Laboratory (HISPEC), Department of Geosciences, National Taiwan University. Chemical procedures followed the methods described in Shen et al. [19]. Detailed instrumental approaches are described in Frohlich et al. [20]. U-Th isotopic data and ${ }^{230} \mathrm{Th}$ dates are shown in Table 1. A total of 479 powdered subsamples (50-100 $\mu \mathrm{g}$ each) were drilled for $\delta^{18} \mathrm{O}$ measurements at $1-\mathrm{mm}$ intervals along the central growth axis using a dental drill with a $0.5 \mathrm{~mm}$ carbide bit. $\delta^{18} \mathrm{O}$ measurements were performed on a Finnigan MAT-253 mass spectrometer, coupled with an on-line automated preparation system, the Kiel Carbonate Device, at the College of Geography Science, Nanjing Normal University. Replicate measurements of an international standard NBS-19 between every 9 samples showed a long-term reproducibility better than $\pm 0.06 \%$. Isotopic data are reported in $\delta$ notation relative to VPDB standard, where $\delta^{18} \mathrm{O}=\left[\left({ }^{18} \mathrm{O} /{ }^{16} \mathrm{O}_{\text {sample }} /{ }^{18} \mathrm{O} /\right.\right.$ $\left.\left.{ }^{16} \mathrm{O}_{\text {std }}\right)-1\right] \times 1000$. 


\subsection{Time series analysis}

To estimate the exact termination of the monsoon Holocene Optimum, a statistical regression approach RAMPFIT was employed. The RAMPFIT is a weighted least-square method that determines a ramp between states of a certain record [21]. This statistical method has been used to estimate the timing, duration and transition process of nine glacial terminations for the European Project for Ice Coring in Antarctica (EPICA) Dome C records [22]. Fleitmann et al. [23] also applied this method to determine transition points of a stalagmite-inferred Holocene Indian Monsoon time series. To understand spatial AM variability during the Holocene Optimum, we applied RAMPFIT to the selected high resolution Holocene $\delta^{18} \mathrm{O}$ records of Qunf Cave [23], Dongge Cave [12], Shigao Cave, Heshang Cave [14] and Sanbao Cave [8] in the Asian Monsoon territory.

\section{Results and discussion}

\section{$2.1{ }^{230}$ Th dates and age model}

Twelve U-Th isotopic compositions and ${ }^{230} \mathrm{Th}$ dates for stalagmite samples SG1 and SG2 are given in Table 1. The stalagmite SG1 has uranium levels of $(0.3-0.5) \times 10^{-6} \mathrm{~g} / \mathrm{g}$ and low thorium contents of $(58-394) \times 10^{-12} \mathrm{~g} / \mathrm{g}$. The uncertainties of corrected ${ }^{230} \mathrm{Th}$ dates, from $9811 \pm 55$ to 4171 \pm 24 a BP (before AD 1950) are $\pm 29-55$ a $(2 \sigma)$. For sample $\mathrm{SG} 2$, the high uranium concentrations of $(1.2-2.2) \times 10^{-6} \mathrm{~g} / \mathrm{g}$ and low thorium levels of $(65-262) \times 10^{-12} \mathrm{~g} / \mathrm{g}$ give good ${ }^{230} \mathrm{Th}$ date precision of $\pm 2.5-28$ a $(2 \sigma)$. Its deposition time interval is from $5663 \pm 22$ to $209.0 \pm 2.5$ a BP (Table 1 ). All ${ }^{230} \mathrm{Th}$ ages are in stratigraphic order, and their uncertainties vary from 4 to $6 \%$. The age models were developed using linear interpolation between ${ }^{230} \mathrm{Th}$ dates (Figure 2).
The age models of stalagmite SG1 and SG2 are illustrated in Figure 2. The SG1 growth rates at depth intervals of 270-96 mm (9.81-6.21 ka BP) and 86-20 mm (5.52-4.17 ka BP) were relatively stable, with an average of 0.048 $\mathrm{mm} / \mathrm{a}$. However, the growth rate between 96 and $86 \mathrm{~mm}$ decreased dramatically to only $0.014 \mathrm{~mm} / \mathrm{a}$. Using a binocular microscope, no clearly visible hiatus could be found, implying a decreasing supply of drip water in the cave during this interval. The SG2 growth rate, $0.039 \mathrm{~mm} / \mathrm{a}$ at $193-130 \mathrm{~mm}(5.66-4.38 \mathrm{ka} \mathrm{BP})$ and $0.049 \mathrm{~mm} / \mathrm{a}$ at $115-10$ $\mathrm{mm}(2.90-0.21 \mathrm{ka} \mathrm{BP})$, was similar to the ones for the SG1 sample. A slow deposition rate of only $0.01 \mathrm{~mm} / \mathrm{a}$ was found at a depth interval of $130-115 \mathrm{~mm}$.

\subsection{Oxygen isotopic records}

The bi-decadal-resolved Shigao Cave stalagmite $\delta^{18} \mathrm{O}$ profile is shown in Figure 3. Chinese stalagmite $\delta^{18} \mathrm{O}$ records have been suggested to reflect variations of monsoonal precipitation on orbital and millennial/centennial timescales [8-13]. Comparison of the recent 1810-a records from Wanxiang Cave [11] and 750-a records from Dayu Cave [10] with drought/flood indices reconstructed from historical documents indicates that stalagmite $\delta^{18} \mathrm{O}$ is mainly dominated by monsoonal rainfall. 50-a meteorological data from Zunyi (data from http://isohis.iaea.org, AD 1951-1998) near Shigao Cave shows that $70 \%-80 \%$ of the yearly precipitation falls in the summer season (April-October), which has a high correlation $\left(r^{2}=0.74\right)$ with yearly rainfall. The weighted rainfall $\delta^{18} \mathrm{O}$ is about $-8.2 \%$ (SMOW) in summer and lower than about $-6.4 \%$ in winter. Accordingly, stalagmite $\delta^{18} \mathrm{O}$ primarily reflects summer EAM precipitation intensity.

The contemporaneous $\delta^{18} \mathrm{O}$ records of SG1 and SG2 at 5.6-4.2 ka BP agree well with one another (Figure 3). This

Table $1{ }^{230}$ Th dating results for stalagmite SG1and SG2 $2^{\text {a) }}$

\begin{tabular}{lccccccccc}
\hline No. & $\begin{array}{c}\text { Depth } \\
(\mathrm{mm})\end{array}$ & $\begin{array}{c}{ }^{238} \mathrm{U} \\
\left(\times 10^{-9} \mathrm{~g} / \mathrm{g}\right)\end{array}$ & $\begin{array}{c}{ }^{232} \mathrm{Th} \\
\left(\times 10^{-12} \mathrm{~g} / \mathrm{g}\right)\end{array}$ & $\begin{array}{c}{ }^{230} \mathrm{Th} /{ }^{232} \mathrm{Th} \\
\left(\text { atomic } \times 10^{-6}\right)\end{array}$ & $\begin{array}{c}\delta^{234} \mathrm{U} \\
(\text { measured })\end{array}$ & $\begin{array}{c}{ }^{234} \mathrm{U}_{\text {Initial }} \\
(\text { corrected })\end{array}$ & $\begin{array}{c}{ }^{230} \mathrm{Th} /{ }^{238} \mathrm{U} \\
\text { (activity) }\end{array}$ & $\begin{array}{c}{ }^{230} \mathrm{Th} \text { age (a) } \\
\text { (uncorrected) }\end{array}$ & $\begin{array}{c}{ }^{230} \mathrm{Th} \text { age (a BP) } \\
\text { (corrected) }\end{array}$ \\
\hline SG1 & 20 & $280.9 \pm 0.6$ & $192.5 \pm 5.9$ & $3146.9 \pm 97.7$ & $2416.8 \pm 10.6$ & $2445.8 \pm 10.7$ & $0.1306 \pm 0.0006$ & $4236 \pm 24$ & $4171 \pm 24$ \\
SG1 & 86 & $304.4 \pm 0.7$ & $58.4 \pm 7.7$ & $14459.7 \pm 1917.4$ & $2353.9 \pm 10.1$ & $2391.3 \pm 10.3$ & $0.1680 \pm 0.0007$ & $5579 \pm 29$ & $5517 \pm 29$ \\
SG1 & 96 & $372.8 \pm 0.8$ & $63.0 \pm 6.7$ & $18174.2 \pm 1942.5$ & $2311.9 \pm 9.7$ & $2353.3 \pm 9.9$ & $0.1860 \pm 0.0006$ & $6272 \pm 28$ & $6211 \pm 28$ \\
SG1 & 155 & $332.4 \pm 0.5$ & $72.8 \pm 6.6$ & $17477.4 \pm 1594.1$ & $2316.3 \pm 7.0$ & $2368.2 \pm 7.2$ & $0.2317 \pm 0.0007$ & $7847 \pm 31$ & $7786 \pm 31$ \\
SG1 & 203 & $328.3 \pm 0.7$ & $283.9 \pm 7.5$ & $5180.7 \pm 137.2$ & $2518.0 \pm 10.0$ & $2580.6 \pm 10.2$ & $0.2713 \pm 0.0011$ & $8685 \pm 44$ & $8619 \pm 44$ \\
SG1 & 270 & $457.7 \pm 1.2$ & $393.8 \pm 5.8$ & $5360.0 \pm 80.8$ & $2198.9 \pm 12.9$ & $2261.1 \pm 13.3$ & $0.2793 \pm 0.0010$ & $9878 \pm 55$ & $9811 \pm 55$ \\
SG2 & 10 & $2228.0 \pm 6.1$ & $65.1 \pm 7.8$ & $2509 \pm 300$ & $803.4 \pm 5.6$ & $804.0 \pm 5.6$ & $0.00444 \pm 0.00004$ & $268.4 \pm 2.5$ & $209 \pm 2.5$ \\
SG2 & 47 & $1882.4 \pm 4.7$ & $262 \pm 10$ & $2382 \pm 95$ & $791.4 \pm 7.1$ & $794.2 \pm 7.1$ & $0.0201 \pm 0.0001$ & $1232 \pm 8$ & $1170 \pm 8$ \\
SG2 & 69 & $2209.8 \pm 5.3$ & $120.7 \pm 7.7$ & $9951 \pm 638$ & $788.5 \pm 5.1$ & $793.0 \pm 5.2$ & $0.0329 \pm 0.0001$ & $2026 \pm 9$ & $1966 \pm 9$ \\
SG2 & 115 & $1728.3 \pm 4.4$ & $95.3 \pm 7.0$ & $14325 \pm 1049$ & $787.4 \pm 5.9$ & $794.0 \pm 5.9$ & $0.0478 \pm 0.0002$ & $2956 \pm 15$ & $2895 \pm 15$ \\
SG2 & 130 & $1547.2 \pm 4.7$ & $76.6 \pm 7.0$ & $24081 \pm 2189$ & $806.3 \pm 6.9$ & $816.5 \pm 7.0$ & $0.0722 \pm 0.0003$ & $4441 \pm 24$ & $4380 \pm 24$ \\
SG2 & 193 & $1204.4 \pm 2.3$ & $183.2 \pm 5.7$ & $10953 \pm 399$ & $967.6 \pm 4.5$ & $983.3 \pm 4.6$ & $0.1009 \pm 0.0003$ & $5725 \pm 22$ & $5663 \pm 22$ \\
\hline
\end{tabular}

a) $\lambda_{230}=9.1705 \times 10^{-6} \mathrm{a}^{-1}, \lambda_{234}=2.8220 \times 10^{-6} \mathrm{a}^{-1}, \lambda_{238}=1.55125 \times 10^{-10} \mathrm{a}^{-1} ; \delta^{234} \mathrm{U}=\left(\left[\left[^{234} \mathrm{U} / /^{238} \mathrm{U}\right]_{\text {activity }}-1\right) \times 1000,{ }^{234} \mathrm{U}_{\text {initial }}=\delta^{234} \mathrm{U}_{\text {measured }} \times \mathrm{e}^{\lambda 234 \times T} ;\right.$ corrected ${ }^{230} \mathrm{Th}$ ages assume the initial ${ }^{230} \mathrm{Th} /{ }^{232} \mathrm{Th}$ atomic ratio of $(4 \pm 2) \times 10^{-6}$ (a BP relative to AD1950). 


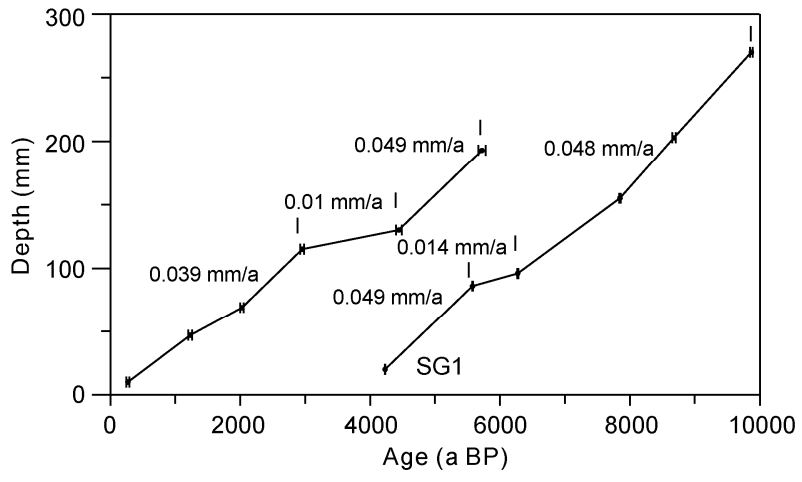

Figure 2 Age models and growth rates of stalagmite samples SG1 and SG2.

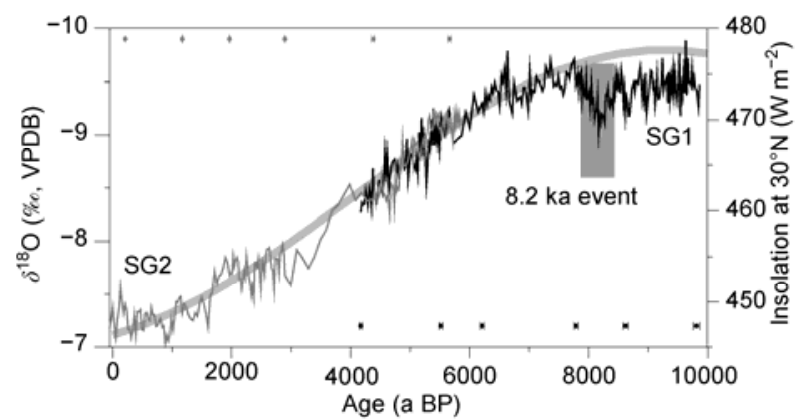

Figure 3 Shigao Cave stalagmite $\delta^{18} \mathrm{O}$ records and insolation curve at $30^{\circ} \mathrm{N}$. Black and gray lines denote $\delta^{18} \mathrm{O}$ records of SG1 and SG2, respectively. The ${ }^{230} \mathrm{Th}$ ages and errors $( \pm 2 \sigma)$ are color-coded by stalagmites.

good replication indicates that the stalagmite deposited under conditions of oxygen isotopic equilibrium, and that kinetic fractionation was inconsequential. The overall trend of this spliced Shigao Cave $\delta^{18} \mathrm{O}$ profile, varying from $-9.6 \%$ o at $9.9 \mathrm{ka} \mathrm{BP}$ to $-7.0 \%$ at present, generally follows midJuly solar insolation at $30^{\circ} \mathrm{N}$, suggesting that $\mathrm{AM}$ intensity was directly controlled by high northern latitude insolation over the entire Holocene.

This profile can be divided with three distinct millennial-scale stages: (1) a humid summit at 9.9-6.6 ka BP; (2) a gradual declining precipitation interval between $6.6-1.6 \mathrm{ka}$ $\mathrm{BP}$; and (3) a relatively dry time window after $1.6 \mathrm{ka}$ BP. It is noticeable that $\delta^{18} \mathrm{O}$ values increased about $1 \%$ within 700 years at $4.0 \mathrm{ka} \mathrm{BP}$, and these values were associated with the slowest growth rate of $0.01 \mathrm{~mm} / \mathrm{a}$. This trend suggests that monsoonal precipitation decreased rapidly during this interval. A similar feature also was recorded in different Chinese caves, such as Sanbao [8] and Heshang [14] (Figure 4). Specifically, the amplitude and duration of this 700-a dry event shown in the Sanbao $\delta^{18} \mathrm{O}$ record [8] also matches our Shigao record.

Centennial-scale oscillations with amplitudes of $0.5 \%$ $1 \%$ are prominent features in the Shigao profile. Our stalagmite record indicates that $\delta^{18} \mathrm{O}$ values abruptly increased at $8.5 \mathrm{ka} \mathrm{BP}$ from $-9.7 \%$ to $-9.2 \%$ and then reached the heaviest value of about $-9.0 \%$ at $8.2 \mathrm{ka} \mathrm{BP}$, followed by a decreasing trend to $7.8 \mathrm{ka}$ BP. This weak AM event at
8.2 ka BP is also evident in other Chinese cave records (Figure 4).

\subsection{Long-term Holocene AM precipitation records and 8.2 ka BP event}

The Asian monsoon system can be divided into two subsystems, the Indian and the East Asian monsoon systems, which are independent of each other and, at the same time, interact with one another [24]. To better understand AM precipitation and the relationship between IM and EAM over the Holocene, we compare our record to those with high temporal resolution and precise chronology from different monsoonal regions. Caves include Qunf $\left(54^{\circ} 18^{\prime} \mathrm{E}\right.$, $17^{\circ} 10^{\prime} \mathrm{N}$ ) in Oman [23] experiencing typical Indian monsoon climate, Sanbao $\left(110^{\circ} 26^{\prime} \mathrm{E}, 31^{\circ} 40^{\prime} \mathrm{N}\right)$ [8] and Heshang $\left(110^{\circ} 25^{\prime} \mathrm{E}, 30^{\circ} 27^{\prime} \mathrm{N}\right)$ [14] from the middle reaches of the Yangtze River, Central China, in the EAM zone, and Dongge $\left(108^{\circ} 5^{\prime} \mathrm{E}, 25^{\circ} 17^{\prime} \mathrm{N}\right)$ [12] and our Shigao study $\left(107^{\circ} 10^{\prime} \mathrm{E}, 28^{\circ} 11^{\prime} \mathrm{N}\right)$ from Southwest China, with local climate influenced by both IM and EAM.

As clearly shown in Figure 4, all stalagmite $\delta^{18} \mathrm{O}$ records

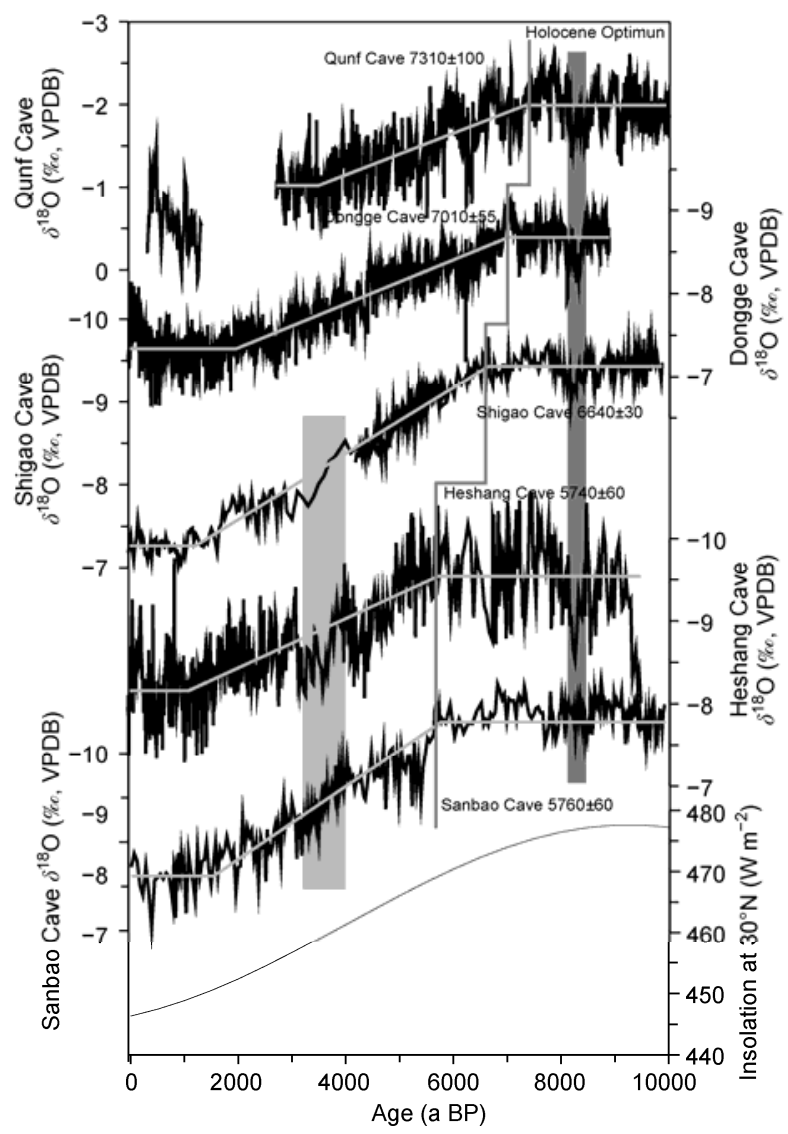

Figure 4 Comparison of the calcite $\delta^{18} \mathrm{O}$ record of stalagmites from Qunf, Dongge, Shigao, Heshang and Sanbao Caves and the solar insolation curve at $30^{\circ} \mathrm{N}$. The gray line represents the best fit using the RAMPFIT program. The vertical lines denote the end of Holocene Optimum and the dark gray vertical bar shows the $8.2 \mathrm{ka} \mathrm{BP}$ event. 
appear to primarily follow orbital forcing. They exhibit a similar feature of the Holocene summer monsoon variation: high precipitation in the early Holocene, a decreasing trend during the middle Holocene, and a relatively weak summer monsoon in the late Holocene. The general consistency of monsoon records from $17^{\circ}-33^{\circ} \mathrm{N}$ indicates an in-phase relationship between the ISM and EASM on orbital timescales over the Holocene. All records clearly track summer insolation, suggesting that the shift in the mean position of the Intertropical Convergence Zone (ITCZ) controls the summer monsoon change throughout the entire mid- to low-latitude regions in Asia [7,23].

The Shigao $\delta^{18} \mathrm{O}$ record shows a distinct weak monsoon event from 8.27 to $8.10 \mathrm{ka} \mathrm{BP}$, characterized by a double-valley structure. This $8.2-\mathrm{ka} \mathrm{BP}$ weak monsoon event is also clearly exhibited in the $\delta^{18} \mathrm{O}$ records in caves of Qunf [23], Dongge [12], and Heshang [14], but only slightly displayed in Sanbao Cave [8]. There is no significant phase difference between sites (Figure 4). It suggests the in-phase millennial-scale variations of EAM and IM could be associated with a southward migration of the westerlies in the Northern Hemisphere [12], which were induced by a slowdown of the Atlantic meridional overturning circulation (AMOC) in the North Atlantic Ocean [25,26].

\subsection{Asynchronous Holocene Optimum termination}

Despite the agreement of orbital-timescale spatial summer AM decreasing trends, regional dissimilarities appear in the detailed declining stalagmite $\delta^{18} \mathrm{O}$ sequences (Figure 4). A statistical regression approach, RAMPFIT [21] was used to objectively determine the ending time of the regional Holocene Optimum for each cave record. The dataset and results are listed in Table 2. The statistically-calculated ramps are depicted in Figure 4. The Holocene Optimum termination commenced as early as $7310 \pm 100$ a BP in the IM area, as shown in the Qunf Cave record, while it occurred later at $5740 \pm 60$ a BP in Heshang Cave and at $5760 \pm 60$ a BP in Sanbao Cave, located in the EAM zone. In Southwest China, where climate is influenced by both IM and EAM, the ending times recorded were 7010 \pm 55 a BP in Dongge Cave and $6640 \pm 30$ a BP in Shigao Cave, and were between the timings in Oman and Central China. Comparisons with the age uncertainties of $<100$ as and temporal resolution of stalag- mite $\delta^{18} \mathrm{O}$ records of $<50$ as, the $200-1000$-a asynchroneity of regional Holocene Optimum terminations is significant, suggesting incoherent regional decreases of the summer monsoon precipitation in Asia after the early Holocene.

Summer AM dynamics are mainly driven by (1) an external forcing, which is affected by the intensity of solar insolation; and (2) internal forcings, such as sea surface temperature of tropical oceans and Hadley Circulation [27]. Changes in these forcings are possible candidates for the asynchronous declining trends of IM and EAM since the early Holocene. The insolation-associated southward movement of the mean ITCZ position has been proposed to cause the weakening of summer AM after $10 \mathrm{ka} \mathrm{BP} \mathrm{[7].} \mathrm{If} \mathrm{this}$ process had controlled the inconsistency of regional rainfall amounts, it would have resulted in an early stalagmite $\delta^{18} \mathrm{O}$ increase recorded in northern China. This argument is opposite to the observations of cave records shown in Figure 4. On the basis of 92 paleoclimatic proxy records from 72 sites, Wang et al. [27] proposed that the development of Hadley Circulation could be the main forcing factor. The authors claimed that solar-insolation intensified Hedley Circulation would have enhanced the summer IM and suppressed the summer EAM before $7 \mathrm{ka} \mathrm{BP}$, and vice versa during 4-7 ka BP. Summer EAM would have reached its maximum with high precipitation in the middle Holocene. Their assumptions are not supported by evidence from stalagmite-inferred strong summer IM and EAM with the highest precipitation before $7.9 \mathrm{ka} \mathrm{BP}$. An absence of maximum rainfall in the EAM realm during 7-4 ka BP (Figure 4) is also in conflict with their proposed Hadley Circulation model.

The IM is a typical tropical monsoon system, driven by insolation-induced sensible heat. The southward migration of the mean ITCZ position, caused by a decreasing southnorth ocean-land thermal gradient, results in a declining rainfall trend in the summer IM territory after $7.3 \mathrm{ka}$ BP [23]. The EAM, dominated by both south-north and eastwest ocean-land thermal gradients, is more complicated than the IM, and its summer rainfall belt (Meiyu belt) is influenced by both tropical and subtropical monsoons [28]. The rain belts of the subtropical front and tropical monsoon trough are coupled to form a meridional extensive rain zone by a profound North Pacific Tropical High, developing by the mainland-Pacific zonal thermal gradient [29].

Table 2 Parameters used for RAMPFIT analysis and the ending time of Holocene Optimum ${ }^{\text {a) }}$

\begin{tabular}{lccrccc}
\hline \multicolumn{1}{c}{ Site } & Ending time of Holocene optimum (a BP) & $n$ & $t(1)$ & $t(n)$ & STD fit & $t 1-t 2$ search (a BP) \\
\hline Shigao Cave & $6640 \pm 30$ & 377 & -51 & 9864 & 0.865 & $-51-2940 / 4940-7940$ \\
Qunf Cave & $7310 \pm 100$ & 1213 & 2700 & 9938 & 0.456 & $2700-3940 / 5940-9938$ \\
Dongge Cave & $7010 \pm 55$ & 2124 & -54 & 8876 & 0.570 & $-54-2940 / 5940-8876$ \\
Heshang Cave & $5740 \pm 60$ & 1223 & -52 & 9468 & 0.631 & $-52-3940 / 3940-7940$ \\
Sanbao Cave & $5760 \pm 60$ & 363 & 10 & 9929 & 0.701 \\
\hline
\end{tabular}

a) $n$ : Number of data point, $t(1)$ : start of interval, $t(n)$ : end of interval, STD fit: standard deviation of data, $t 1-t 2$ search: intervals from which $t 1 / t 2$ were chosen. 
Modern meteorological data [30] show a precipitation anti-phasing between the summer IM and EAM on annualto decadal-timescales. With a concurrent decreasing ISM, EASM is intensified with northward movement of the Meiyu band, which results in abundant rainfall in central and northern China. In this case, these regions experienced much greater amounts of moisture from the Pacific Ocean than from the Indian Ocean. Modern instrumental data also indicate that a high-SST western tropical Pacific could have enhanced upper convection from the Philippines to the Sino-India Peninsula via the South China Sea, which would have forced the subtropical high over East Asia to move northward and resulted in the northward shift of the monsoon front and rain band. This would have brought more precipitation to central and northern China [31]. Model simulation results also confirmed that a rise in the western tropical Pacific SST could have increased summer rainfall in central and northern China [32]. Marine sediment geochemical proxy records infer a high thermal condition in the western tropical Pacific in the early-middle Holocene, followed by a decreasing trend since $\sim 5 \mathrm{ka}$ BP [33]. When ISM began to decrease and insolation-driven ITCZ migrated southward after 7.3 ka BP, the prevailing EASM, strengthened by the warm western tropical Pacific, enhanced landward advection of moisture and heat to the middle Yangtze River and Shennongjia districts at least before $5.7 \mathrm{ka} \mathrm{BP}$. Accordingly, we propose that the strong EASM during the middle-early Holocene intensified precipitation in Southwest China and caused a delayed onset of decreasing precipitation trend at $6.6 \mathrm{ka} \mathrm{BP}$, as evidenced by our Shigao Cave $\delta^{18} \mathrm{O}$ records.

\section{Conclusions}

The stalagmite $\delta^{18} \mathrm{O}$ time series from Shigao Cave in northern Guizhou Province, Southwest China, over the past 9.9 ka BP reveals precipitation records and ASM variability since the Early Holocene. Agreement of cave $\delta^{18} \mathrm{O}$ trends in different Asian monsoon regions indicates that solar insolation in the northern hemisphere was the primarily forced on ASM intensity over the entire Holocene. Cave $\delta^{18} \mathrm{O}$ records also show an asynchronous termination of the regional monsoon Holocene Optimum of 7.2-7.4 ka BP in Oman, located in the IM region, 5.6-5.8 ka BP in Central China, located in the EAM zone, and 6.6-7.0 ka BP in Southwest China. This timing discrepancy may be attributed to Holocene SST dynamics in the western tropical Pacific, the main EASM moisture source.

The authors thank K. Lin ( $\mathrm{CoCo}$ ) for her assistance in the laboratory. Constructive reviews by two anonymous reviewers significantly improved this paper. This work was supported by the National Natural Science Foundation of China (41002061 and 40771009) and the Natural Science Foundation of Fujian Province (2010J05093). Funding was also provided by NSC grants (NSC 99-2611-M-002 -006, 99-2628-M-002-012 to C.-C. S.).
1 An Z S, Porter S C, Kutzbach J E, et al. Asynchronous Holocene optimum of the East Asian monsoon. Quat Sci Rev, 2000, 19: 743-762

2 He Y, Theakstone W H, Zhang Z L, et al. Asynchronous Holocene climatic change across China. Quat Res, 2004, 61: 52-63

3 Hong Y T, Hong B, Lin Q H, et al. Synchronous climate anomalies in the western North Pacific and North Atlantic regions during the last 14000 years. Quat Sci Rev, 2009, 28: 840-849

4 Jiang W Y, Guo Z T, Sun X J, et al. Reconstruction of climate and vegetation changes of Lake Bayanchagan (Inner Mongolia): Holocene variability of the East Asian monsoon. Quat Res, 2006, 65: 411-420

5 Jung S J A, Davies G R, Ganssen G M, et al. Synchronous Holocene sea surface temperature and rainfall variations in the Asian monsoon system. Quat Sci Rev, 2004, 23: 2207-2218

6 Yancheva G, Nowaczyk N R, Mingram J, et al. Influence of the intertropical convergence zone on the East Asian monsoon. Nature, 2007, 445: 74-77

7 Fleitmann D, Burns S J, Manginic A, et al. Holocene ITCZ and Indian monsoon dynamics recorded in stalagmites from Oman and Yemen (Socotra). Quat Sci Rev, 2007, 26: 170-188

8 Dong $\mathrm{J} \mathrm{G}$, Wang Y J, Cheng $\mathrm{H}$, et al. A high-resolution stalagmite record of the Holocene East Asian monsoon from Mt Shennongjia, central China. Holocene, 2010, 20: 257-264

9 Cai Y J, Tan L C, Cheng H, et al. The variation of summer monsoon precipitation in central China since the last deglaciation. Earth Planet Sci Lett, 2010, 291: 21-31

10 Tan L C, Cai Y J, Cheng H, et al. Summer monsoon precipitation variations in central China over the past 750 years derived from a high-resolution absolute-dated stalagmite. Palaeogeogr Palaeoclimatol Palaeoecol, 2009, 280: 432-439

11 Zhang P Z, Cheng H, Edwards R L, et al. A test of climate, sun, and culture relationships from an 1810-year Chinese cave record. Science, 2008, 322: 940-942

12 Wang Y J, Cheng H, Edwards R L, et al. The Holocene Asian Monsoon: Links to solar changes and North Atlantic climate. Science, 2005, 308: 854-857

13 Shao X H, Wang Y J, Cheng H, et al. Long-term trend and abrupt events of the Holocene Asian monsoon inferred from a stalagmite $\delta^{18} \mathrm{O}$ record from Shennongjia in Central China. Chin Sci Bull, 2006, 51: 221-228

14 Hu C Y, Henderson G M, Huang J H, et al. Quantification of Holocene Asian monsoon rainfall from spatially separated cave records. Earth Planet Sci Lett, 2008, 266: 221-232

15 Shi Y F, Kong Z C, Wang S M, et al. The climatic fluctuations and important events of Holocene Megathermal in China. Sci China Ser B, 1992, 22: 1300-1308

16 Sun Q L, Xiao J L. Characteristics of the Holocene optimum in the monsoon/arid transition belt record by core sediments of Daihai Lake, north China. Quat Sci, 2006, 26: 781-790

17 Zhou W J, Song S H, Burr G, et al. Is there a time-transgressive Holocene Optimum in the East Asian monsoon area? Radiocarbon, 2007, 49: $865-875$

18 Wang S Y, Lü H Y, Liu J Q, et al. The early Holocene optimum inferred from a high-resolution pollen record of Huguangyan Maar Lake in southern China. Chin Sci Bull, 2007, 52: 2829-2836

19 Shen C C, Cheng H, Edwards R L, et al. Measurement of attogram quantities of ${ }^{231} \mathrm{~Pa}$ in dissolved and particulate fractions of seawater by isotope dilution thermal ionization mass spectroscopy. Anal Chem, 2003, 75: 1075-1079

20 Frohlich C, Hornbach M J, Taylor F W, et al. Huge erratic boulders in Tonga deposited by a prehistoric tsunami. Geology, 2009, 37: $131-134$

21 Mudelsee M. Ramp function regression: A tool for quantifying climate transitions. Comput Geosci, 2000, 26: 293-307

22 Röthlisberger R, Mudelsee M, Bigler M, et al. The Southern Hemisphere at glacial terminations: Insight from the Dome $\mathrm{C}$ ice core. Clim Past, 2010, 4: 345-356

23 Fleitmann D, Burns S J, Mudelsee M, et al. Holocene Forcing of the Indian Monsoon Recorded in a Stalagmite from Southern Oman. Science, 2003, 300: 1737-1739 
24 Tao S Y, Chen L. A review of recent research on East Asian summer monsoon in China. In: Chang C P, Krishnamurti T N, eds. Monsoon Meteorology. Oxford: Oxford University Press, 1987. 60-92

25 Bond G, Kromer B, Beer J, et al. Persistent solar influence on North Atlantic climate during the Holocene. Science, 2001, 294: 2130-2136

26 Bond G, Showers W, Cheseby M, et al. A Pervasive millennial-scale cycle in North Atlantic Holocene and glacial climates. Science, 1997, 278: $1257-1266$

27 Wang Y B, Liu X Q, Herzschuh U. Asynchronous evolution of the Indian and East Asian Summer Monsoon indicated by Holocene moisture patterns in monsoonal central Asia. Earth Sci Rev, 2010, 103: $135-153$

28 Wang B, Lin H. Rainy season of the Asian-Pacific summer monsoon. J Clim, 2002, 15: 386-396
29 Wang B, Clemens S C, Liu P. Contrasting the Indian and East Asian monsoons: Implications on geologic timescales. Mar Geol, 2003, 201: $5-21$

30 Liu J, Wang B, Yang J. Forced and internal modes of variability of the East Asian summer monsoon. Clim Past, 2008, (2): 225-233

31 Huang R, Huang G, Wei Z G. Climate variations of the summer monsoon over China. In: Chang C P, ed. East Asian Monsoon. Singapore: World Scientific Publishing Co. Pte. Ltd, 2004. 213-268

32 Liu Z, Otto-Bliesner B, Kutzbach J, et al. Coupled climate simulation of the evolution of global monsoons in the Holocene. J Clim, 2003, 16: $2472-2490$

33 Stott L, Cannariato K, Thunell R, et al. Decline of surface temperature and salinity in the western tropical Pacific Ocean in the Holocene epoch. Nature, 2004, 431: 56-59

Open Access This article is distributed under the terms of the Creative Commons Attribution License which permits any use, distribution, and reproduction in any medium, provided the original author(s) and source are credited. 